\title{
Potential Evapotranspiration and Crop Coefficient Estimates for Sugarcane in Okinawa
}

\author{
Md. Akbar HOSSAIN, Masami UENO, Kenjiro MAEDA* and Yoshinobu KAWAMITSU \\ Faculty of Agriculture, University of the Ryukyus, Nishihara-cho, Okinawa 903-0213, Japan. \\ *The United Graduate School of Agricultural Sciences, Kagoshima University, Kagoshima 890-0065, Japan.
}

\begin{abstract}
Seven empirical ET-calculation models (Penman Modified, FAO Penman-Monteith, Priestly-Taylors, Doorenbos-Pruit's Modified FAO Penman, FAO Blaney-Criddle, FAO 24 Radiation and Jensen-Haise) were evaluated from 1980-2003 to estimate the potential evapotranspiration (ETp), crop coefficients $(K c)$ and crop water requirements $(E T C)$ for sugarcane grown in nine locations on Southwest Islands of Japan (Naha-Okinawa south, Nago-Okinawa north, Kume, Minami Daito, Ishigaki, Miyako, Yonaguni, Iriomote and Izena). The FAO Penman-Monteith model showed the most reliable estimates of ETp. The mean of monthly ETp, ETc and Kc were higher in Ishigaki, Miyako, Minami Daito and Yonaguni compared to Naha, Kume, and Iriomote, while these were low for Nago and Izena. The values of ETp, ETc and $K c$ for all islands increased gradually from January (summer cane) and April (spring cane), reached the peak in July-October, and thereafter decreased gradually to February of the following year. The $K c$ values of summer and spring planted sugarcane reached a maximum during June to September (1.10-1.24) and July to October (1.17-1.41) respectively. Overall, the $K c$ values of spring cane were higher than the summer cane and the values declined around 0.50 (summer) and 0.54 (spring) at the end of growing season. A long-term analysis of effective rainfall revealed that $485 \pm 125 \mathrm{~mm}$ annual water shortage prevails in these islands. Seasonal water demand in Ishigaki, Miyako, Minami Daito, and Naha was higher compared to other islands.
\end{abstract}

Key words: Crop coefficient, Crop water requirement, Effective rainfall, Water deficit.

\section{Introduction}

Sugarcane is a main crop in Okinawa. About $70 \%$ of farmers are engaged in its production. Annual productions of this crop have decreased from 2.43 million tons to less than 1.00 million tons in recent years since 1965. The present average yield of sugarcane is 58.3 tha (Annon, 2002-03). Drought in the summer season (July-October) is the major constraint in the production because the rainfall is mostly concentrated in the rainy season and in the typhoon season, which occurs in the dry summer period. Despite much rainfall $(2200 \pm 550 \mathrm{~mm})$, there are no big rivers or reservoirs for water storage to meet the water demand in the dry periods.

Most of the sugarcane-growing islands in Okinawa, except Okinawa Main Island comprising Naha and Nago, have no proper irrigation schedules. Farmers in these islands practice irrigation based on their own experiences, which cause under or over-irrigation with potential effects on production cost. Therefore, information on evapotranspiration $(E T)$ and crop coefficients $(K c)$ of sugarcane is important for irrigation scheduling through better utilization of the limited water resources in the dry period. In the absence of actual data on water requirements, there is no alternative to predict the accurate evapotranspiration of crops. The concept of a daily potential evapotranspiration $(E T p)$ is widely used in the estimation of crop water requirements where studies on field water balance are lacking and meteorological data are adequate (Jensen et al. 1990).

A large number of models for $E T$-estimation have been developed elsewhere, which can be evaluated for the most suitable model in estimating ETp in the subtropic humid climates of Okinawa, incorporating local meteorological data. The modified Penman-Monteith model (Allen et al. 1994) employed with adequate data on canopy and aerodynamic resistances could measure more accurate ETp estimates than other methods. The long-term ETp could be estimated using the most suited $E T$-estimation model, rather than the Penman-Monteith model (Allen et al. 1994), due to inadequacy of data on stomatal resistance, wind dynamics and surface roughness. The $K c$ is an important parameter, which can be estimated by dividing the daily crop water requirements (ETC) obtained from lysimeter/ field water balance studies by the predicted ETp. Therefore, the objectives of this study are to: (1) evaluate the most suitable ETestimation model for the islands of Okinawa, (2) estimate the long-term average ETP and $K c$, which will provide a means for estimating actual crop evapotranspiration for summer and spring-planted sugarcane, and (3) analyze the effective rainfall and water deficits in the islands of Okinawa. 


\section{Materials and Methods}

\subsection{Study Areas and Investigation Period}

This investigation was carried out for the allied islands of Okinawa Prefecture $\left(24^{\circ} 19.9^{\prime}-26^{\circ} 3.4^{\prime} \mathrm{N}\right)$. The nine locations on these southwest islands of Japan were Naha-Okinawa south, Nago-Okinawa north, Kume, Minami Daito, Ishigaki, Miyako, Yonaguni, Iriomote and Izena. Soils in these islands are locally classified as Shimajiri Maji and Kunigami Maji (Luvisols/Cambisols, FAO). The field capacity, wilting point and bulk density of these soils are $0.40 \pm$ $0.15 \mathrm{~m}^{3} \mathrm{~m}^{-3}, 0.20 \pm 0.05 \mathrm{~m}^{3} \mathrm{~m}^{-3}$ and $1.14 \pm 0.45 \mathrm{kgm}^{-3}$. The investigation was conducted over 23 years (1980-2003) for summer (Jan.-Feb. of the following year) and spring (Apr.-Feb. of the following year) planted sugarcane.

\subsection{Meteorological Data}

The daily meteorological data on average temperature, solar radiation, relative humidity, vapor pressure, wind speed, and sunshine, were collected from automatic weather stations and the office of the Okinawa Met. Observatory.

\subsection{Potential evapotranspiration}

Seven energy balance ET-estimation equations such as: (1) Penman Model, 1956; (2) FAO PenmanMonteith (Allen et al. 1998); (3) Priestly-Taylors, 1972; (4) Doorenbos and Pruit's Modified Penman, 1977; (5) FAO Blaney-Criddle (Allen \& Pruitt, 1986); (6) FAO 24 Radiation; and (7) Jensen-Haise, 1963 (Penman, 1956; Reference Evapotranspiration Models [Online], 2004), have been evaluated to check the best-suited model for estimation of ETp of the study areas. The applicability of these equations was correlated with well-watered lysimeter ET of sugarcane to check the best-fitted model for Okinawa.

\subsection{Actual Evapotranspiration \& Crop Coefficient}

Actual measured evapotranspiration data for summer and spring cane was available from field water balance lysimeter studies conducted in Naha for 1967-86 (Yamashiro, 1990) and 1999-02 (Yoshinaga and Hossain, 2003) respectively. Regression models for summer and spring cane were developed using the lysimeter measured ETc and locally available weather variables to calculate the long-term $E T c$. Further, the predicted regression ETC was fitted with the Gauss method to calculate the missing values and to minimize the deviation in daily ETc. Crop coefficients $(K c)$ were computed as the ratio of daily ETC and ETp $(K c=E T c / E T p)$.

2.5 Effective rainfall and annual water shortage

Daily rainfall equal to or greater than $5 \mathrm{~mm}$ with 80 percent efficiency is considered to be effective rainfall, which was calculated as follows:

"ER $(\mathrm{mm} /$ day $)=($ Daily rainfall $\geq 5 \mathrm{~mm}) \times 0.8 "$. In Okinawa, soil water is usually depleted to critical level within 7 to 15 days after irrigation or rainfall (Yamashiro et al. 1994). Therefore, the criteria to estimate the effective rainfall and soil water deficits for every 10 days period were as follows:

(1) If $\sum_{n=1}^{10} E R \geq \sum_{n=1}^{10} E T_{c}$, then irrigation (I) $=0 \mathrm{~mm}$, and

(2) If $\sum_{n=1}^{10} E R<\sum_{n=1}^{10} E T_{c}$, then I $=\left(\sum_{n=1}^{10} E T_{c}-\sum_{n=1}^{10} E R\right) \mathrm{mm}$.

Statistical analyses were done using the SPSS Package.

\section{Results and Discussion}

Seven energy balance ET-estimation models were evaluated for different islands to check the best-fitted model for estimation of ETp. The FAO PenmanMonteith model (Allen et al. 1998) showed the most reliable estimates of ETp (1342-1699 $\mathrm{mm})$, as the closeness of fit ' $R^{2}$ ' value of the model was comparatively higher than other models (Table 1). FAO Radiation and Jensen-Haise methods tended to overestimate the ETp rates during the peak growth period (July-October) and the annual estimates were high $(1792-2472 \mathrm{~mm})$ due to fluctuation of weather parameters. However, the FAO Blaney-Criddle method estimated an unexpected low annual ETP $(750-981 \mathrm{~mm})$ that occurred due to in adjustment of weather parameters in the model for these sub-tropic humid climates.

Depending upon the best fit, the FAO PenmanMonteith model (Allen et al. 1998) was used to estimate ETp in the islands of Okinawa (Fig. 1). Significantly high rates of ETp were recorded in Ishigaki followed by Miyako, Minami Daito, Naha

Table 1. Fitness of models: values are the seasonal potential evapotranspiration (mean of 1980-2003).

\begin{tabular}{lccccccc}
\hline Study area & Modified PM & FAO PM-Monteith & Priestly-Taylor & Dooren.-Pruit & Blaney-Cridle & Radiation & Jensen-Haise \\
\hline Naha & $1699\left(0.93^{*}\right)$ & $1468(0.94)$ & $1373(0.88)$ & $1328(0.90)$ & $891(0.86)$ & $1677(0.90)$ & $1988(0.87)$ \\
Nago & $1553(0.92)$ & $1342(0.93)$ & $1373(0.88)$ & $1307(0.89)$ & $778(0.90)$ & $1662(0.90)$ & $1943(0.90)$ \\
Kume & $1688(0.93)$ & $1458(0.94)$ & $1377(0.88)$ & $1328(0.89)$ & $778(0.89)$ & $1654(0.90)$ & $2136(0.91)$ \\
Miyako & $1705(0.93)$ & $1467(0.94)$ & $1486(0.87)$ & $1387(0.89)$ & $783(0.89)$ & $1749(0.88)$ & $2171(0.91)$ \\
Minami Daito & $1772(0.90)$ & $1511(0.91)$ & $1583(0.86)$ & $1470(0.87)$ & $915(0.83)$ & $1895(0.86)$ & $2214(0.90)$ \\
Ishigaki & $1873(0.91)$ & $1615(0.93)$ & $1503(0.87)$ & $1422(0.88)$ & $813(0.85)$ & $1773(0.88)$ & $2299(0.89)$ \\
Yonaguni & $2005(0.91)$ & $1699(0.92)$ & $1626(0.85)$ & $1518(0.86)$ & $750(0.86)$ & $1861(0.86)$ & $2472(0.92)$ \\
Iriomote & $1620(0.89)$ & $1380(0.90)$ & $1457(0.84)$ & $1421(0.85)$ & $789(0.83)$ & $1691(0.85)$ & $1792(0.91)$ \\
Izena & $1666(0.89)$ & $1421(0.93)$ & $1362(0.85)$ & $1294(0.86)$ & $798(0.86)$ & $1655(0.86)$ & $1984(0.91)$
\end{tabular}

*Parentheses are the closeness of fit ' $R$ ' values comparing with well-watered lysimeter ET of sugarcane. 


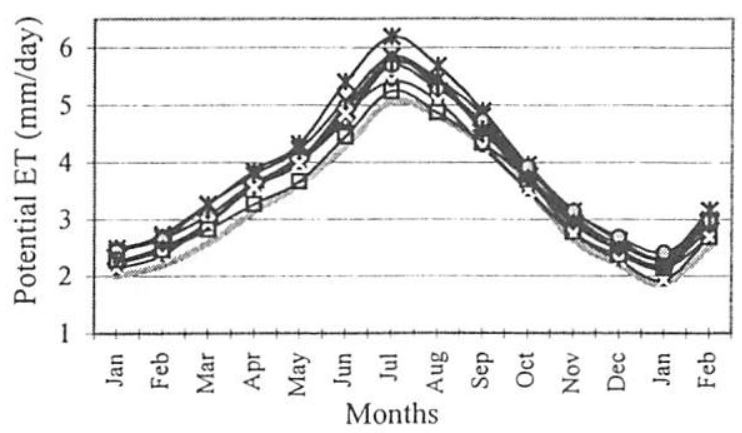

\begin{tabular}{lll}
\hline -Naha & Nago & $-\Delta$ Kume \\
$\rightarrow$-Miyako & $\rightarrow$-Ishigaki & - - Minami Daito \\
- Yonaguni & - -Iriomote & $-\square$-Izena
\end{tabular}

Fig. 1. Potential evapotranspiration of crops in the islands of Okinawa (Penman Monteith model).

and Kume. Lower ETp was recorded in Nago, Izena and Iriomote. The peak ETp $(5.07-6.19 \mathrm{~mm} /$ day $)$ was observed during July-August. High temperature and radiation due to geographical position and comparatively low forest cover caused the high rate of ETp of crops in Ishigaki, Miyako, Minami Daito, Naha and Kume. Moreover, analysis of 23 years weather data depicted $1 \pm 0.34^{\circ} \mathrm{C}$ increment in annual air temperature that may have caused the increase in crop evapotranspiration.

The Gauss fitted long-term regional ETc calculated by using the regression models are presented in Table 2. In the early and later seasons in the year, the ETC was low compared to ETp (Fig. 1 and Table 2). The growth rate, canopy dependant variable and $K c$ were responsible for minimizing the $E T C$ in early and later growth periods. However, ETc peaked in July-October, which exceeded the ETp values. High leaf area index and the function of stomata transpired much water in this stage. The Gauss fitted regression ETc was in quite good agreement with the lysimeter measured $E T c$, as the value of $R^{2}$ was 0.97 and there was standard error of estimates (SEE) of $0.31 \mathrm{~mm}$ per day at $P=0.01$ (Fig. 2). Further, Fig. 2 reveals the lower value of $R^{2}=0.87(S E E=0.42 \mathrm{~mm}$ per day), which shows the moderate relationship between model ETp and lysimeter measured ETC. The high values of ETC

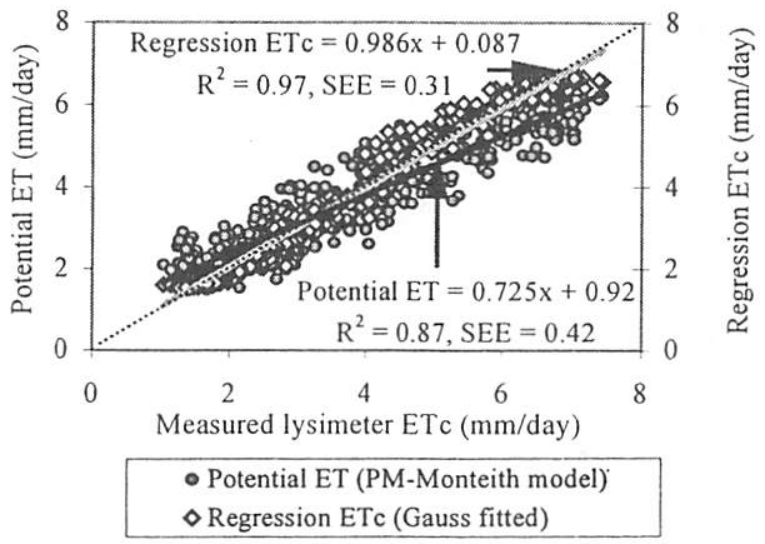

Fig. 2. Relationships of lysimeter ETc between regression ETc (Gauss fitted) and potential ET.

were found in Ishigaki, Minami Daito and Yonaguni Islands, which might be significantly influenced by the prevailing high temperature, wind speed and clear sunshine in these regions.

In irrigation scheduling, crop coefficient factors for different locations depending upon the growth stages are more effective to estimate ETC of a special crop when multiplying with ETp. Overall, $K c$ was lower in the early stage, gradually increased at the onset of increasing stem elongation, reached a peak in JulyAugust, and decreased further retaining constant values during crop harvest (Table 3). As these results indicate, sugarcane consumes much water in the peak growth stage, with lower consumption in the early and later stages. The $K c$ values in the peak growth stages were higher for spring cane over summer cane. Further, the $K c$ values in Ishigaki, Minami Daito, Yonaguni and Miyako were higher than for the other islands (Table 3).

In common years, the sugarcane receives $816 \pm 74$ $\mathrm{mm}$ effective rainfall with annual water shortage of $483 \pm 125 \mathrm{~mm}$ (Fig. 3). Yamashiro et al. (1994) reported 813 and $482 \mathrm{~mm}$ for annual average effective rainfall and water deficit, respectively in Naha and Miyako Island. The water deficits were very uncommon in the early and later-seasons because rainfall was more effective in meeting the water

Table 2. Crop water requirements (ETc) for summer and spring (parentheses) sugarcane (mean of 1980-2003).

\begin{tabular}{lllllllllr}
\hline Months & Naha & Nago & Kume & Miyako & $\begin{array}{c}\text { Minami } \\
\text { Daito }\end{array}$ & Ishigaki & Yonaguni & Iriomote & Izena \\
\hline Jan & 1.5 & 1.2 & 1.3 & 1.5 & 1.5 & 1.5 & 1.3 & 1.3 & 1.2 \\
Feb & 1.9 & 1.5 & 1.8 & 1.9 & 1.9 & 1.9 & 1.7 & 1.7 & 1.6 \\
Mar & 2.5 & 2.1 & 2.3 & 2.4 & 2.6 & 2.6 & 2.4 & 2.3 & 2.2 \\
Apr & $3.3(1.7)$ & $2.8(1.7)$ & $3.2(1.7)$ & $3.3(1.7)$ & $3.4(1.8)$ & $3.5(1.8)$ & $3.2(1.7)$ & $3.2(1.7)$ & $3.1(1.5)$ \\
May & $4.2(3.2)$ & $3.7(3.2)$ & $4.1(3.1)$ & $4.1(3.1)$ & $4.3(3.3)$ & $4.4(3.4)$ & $4.1(3.1)$ & $4.0(3.1)$ & $3.7(2.8)$ \\
Jun & $5.5(4.7)$ & $4.8(4.6)$ & $5.3(4.5)$ & $5.5(4.7)$ & $5.6(4.8)$ & $6.0(5.1)$ & $5.5(4.7)$ & $5.4(4.6)$ & $4.7(4.2)$ \\
Jul & $6.7(5.9)$ & $5.9(5.9)$ & $6.7(5.9)$ & $6.7(5.8)$ & $6.8(6.0)$ & $7.2(6.4)$ & $6.8(5.9)$ & $6.3(5.6)$ & $5.8(5.4)$ \\
Aug & $6.3(6.4)$ & $5.8(6.7)$ & $6.6(6.8)$ & $6.4(6.7)$ & $6.5(6.9)$ & $6.9(7.1)$ & $6.5(6.6)$ & $6.1(6.4)$ & $5.5(6.2)$ \\
Sep & $5.5(5.4)$ & $5.1(5.5)$ & $5.5(5.4)$ & $5.5(5.4)$ & $5.6(5.7)$ & $5.8(5.7)$ & $5.4(5.5)$ & $5.1(5.2)$ & $4.8(5.1)$ \\
Oct & $4.1(4.2)$ & $3.7(4.1)$ & $4.0(4.0)$ & $4.1(4.2)$ & $4.0(4.1)$ & $4.2(4.3)$ & $3.9(4.0)$ & $3.7(3.8)$ & $3.9(4.0)$ \\
Nov & $2.8(2.5)$ & $2.4(2.5)$ & $2.7(2.5)$ & $2.8(2.6)$ & $2.7(2.5)$ & $2.9(2.6)$ & $2.6(2.7)$ & $2.5(2.4)$ & $2.7(2.4)$ \\
Dec & $1.9(1.8)$ & $1.6(1.7)$ & $1.8(1.7)$ & $2.0(1.9)$ & $1.9(1.7)$ & $2.0(1.8)$ & $1.8(1.7)$ & $1.7(1.6)$ & $2.0(1.7)$ \\
Jan & $1.4(1.8)$ & $1.2(1.3)$ & $1.4(1.3)$ & $1.5(1.5)$ & $1.4(1.3)$ & $1.5(1.5)$ & $1.3(1.3)$ & $1.2(1.2)$ & $1.4(1.3)$ \\
Feb & $1.3(1.3)$ & $1.0(1.2)$ & $1.2(1.2)$ & $1.3(1.3)$ & $1.2(1.2)$ & $1.3(1.3)$ & $1.2(1.2)$ & $1.1(1.1)$ & $1.3(1.2)$ \\
\hline
\end{tabular}


Table 3. Crop coefficients of summer and spring (parentheses) planted sugarcane over 23 years (1980-2003).

\begin{tabular}{llllllllll}
\hline Month & \multicolumn{1}{c}{ Naha } & Nago & Kume & Miyako & MinamiDaito & Ishigaki & Yonaguni & Iriomote & Izena \\
\hline Jan & 0.60 & 0.61 & 0.60 & 0.60 & 0.60 & 0.60 & 0.61 & 0.60 & 0.50 \\
Feb & 0.70 & 0.71 & 0.70 & 0.68 & 0.72 & 0.70 & 0.69 & 0.70 & 0.68 \\
Mar & 0.80 & 0.81 & 0.80 & 0.75 & 0.86 & 0.80 & 0.80 & 0.80 & 0.83 \\
Apr & $0.90(0.48)$ & $0.89(0.47)$ & $0.87(0.49)$ & $0.87(0.46)$ & $0.93(0.48)$ & $0.91(0.54)$ & $0.90(0.49)$ & $0.90(0.49)$ & $0.96(0.45)$ \\
May & $1.01(0.77)$ & $1.02(0.77)$ & $1.01(0.79)$ & $0.97(0.75)$ & $1.05(0.78)$ & $1.02(0.86)$ & $1.01(0.79)$ & $1.01(0.78)$ & $1.02(0.73)$ \\
Jun & $1.13(1.02)$ & $1.12(1.02)$ & $1.11(1.03)$ & $1.09(0.96)$ & $1.13(0.98)$ & $1.11(1.10)$ & $1.12(1.00)$ & $1.11(0.99)$ & $1.05(0.91)$ \\
Jul & $1.16(1.11)$ & $1.17(1.10)$ & $1.17(1.12)$ & $1.14(1.09)$ & $1.20(1.12)$ & $1.17(1.22)$ & $1.19(1.17)$ & $1.17(1.10)$ & $1.10(1.03)$ \\
Aug & $1.18(1.24)$ & $1.22(1.23)$ & $1.21(1.22)$ & $1.17(1.29)$ & $1.24(1.26)$ & $1.21(1.36)$ & $1.25(1.31)$ & $1.21(1.23)$ & $1.12(1.16)$ \\
Sep & $1.17(1.29)$ & $1.19(1.31)$ & $1.19(1.32)$ & $1.14(1.30)$ & $1.19(1.32)$ & $1.19(1.41)$ & $1.19(1.42)$ & $1.18(1.34)$ & $1.10(1.25)$ \\
Oct & $1.05(1.20)$ & $1.04(1.23)$ & $1.05(1.24)$ & $1.09(1.24)$ & $1.01(1.19)$ & $1.05(1.27)$ & $1.05(1.34)$ & $1.05(1.27)$ & $1.06(1.18)$ \\
Nov & $0.90(1.01)$ & $0.91(1.04)$ & $0.90(1.04)$ & $0.94(1.03)$ & $0.86(0.99)$ & $0.90(1.08)$ & $0.90(1.13)$ & $0.90(1.07)$ & $0.97(0.99)$ \\
Dec & $0.76(0.81)$ & $0.75(0.85)$ & $0.74(0.86)$ & $0.82(0.84)$ & $0.69(0.77)$ & $0.75(0.88)$ & $0.75(0.91)$ & $0.75(0.85)$ & $0.82(0.78)$ \\
Jan & $0.62(0.65)$ & $0.62(0.69)$ & $0.62(0.69)$ & $0.68(0.68)$ & $0.57(0.62)$ & $0.62(0.70)$ & $0.62(0.78)$ & $0.62(0.70)$ & $0.64(0.64)$ \\
Feb & $0.50(0.53)$ & $0.49(0.56)$ & $0.51(0.56)$ & $0.55(0.55)$ & $0.46(0.51)$ & $0.50(0.58)$ & $0.50(0.61)$ & $0.50(0.56)$ & $0.57(0.52)$ \\
\hline
\end{tabular}

demand during these seasons. Low effective rainfall in the dry period (July-October) failed to meet the potential water demand (Table 2 and Fig. 3). The standard deviations (STD) of effective rainfall indicate a greater fluctuation in rainfall during July-October, which causes severe drought with a remarkable yield loss in the islands of Okinawa (Fig. 3). The high values of STD occurred in July to October due to low effective rainfall. This deviation in effective rainfall caused severe drought during 1963, 1971, 1994, and 1997 with yield losses of 60, 90, 50 and 45\% respectively (Yamashiro et al. 1994; Anon, 2002-03). Overall, $350 \pm 53 \mathrm{~mm}$ supplemental irrigation is needed during July-October to save sugarcane from drought damage and to optimize the yield in the islands of Okinawa (Fig. 3).

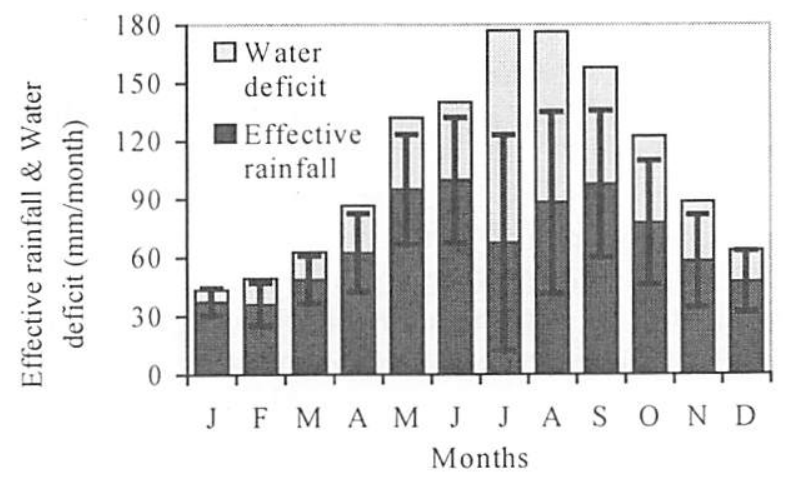

Fig. 3. Effective rainfall and water deficits in Okinawa (Ave. of all sites for 1980-03, Bar: STD of effect. rain).

\section{Conclusions}

(a) The simplified FAO Penman-Monteith model is the best-fitted model for Okinawa.

(b) In the dry period (July-October), irrigation could be applied at 10 day intervals as "Irrigation depth for 10 days $(\mathrm{mm})=(\Sigma$ Actual ET for 10 days $)$ ( $\Sigma$ Effective rainfall for 10 days)".

(c) The database of this study, especially ET obtained from empirical models and meteorological data, would be worth comparing with the reflection based $E T$ and $K c$ to be employed for Okinawa in the near future. (d) Advanced technology "Remote sensing and GIS" would possibly be suitable in evaluating evapotranspiration in comparison with these findings and for growth analysis of sugarcane in the islands of Okinawa.

\section{Acknowledgement}

The authors thank the authority of Japan Society for the Promotion of Science for financial support in doing this work.

\section{References}

Allen, R.G., Pereira, L.S., Raes, D. and Smith, M., 1998: Crop Evapotranspiration: Guidelines for computing crop water requirements, FAO Irrig. and Draina. Paper No. 56, FAO, Rome, Italy.

Allen, R.G., Smith, M., Pereira, L.S., and Perrier, A., 1994: An update for the calculation of reference evapotranspiration. ICID Bull. 43(2):35-92.

Anonymous, 2002-03: Production report of sugarcane and sugar: Aug. 2003 (Japanese). Dept of Agril., Forestry and Fisheries, Okinawa, Japan, 55-60pp.

Jensen, M .E., Burman, R.D., and Allen, R.G., 1990: Evapotranspiration and irrigation water requirements. ASCE Manual \& Reports on Engg. Practice. No.70.

Penman, H. L., 1956: Estimating evapotranspiration. Trans. Geophs. Union, 37:44-46.

Reference Evapotranspiration Models, 2004: [Online] Available at:http://etd.Isu/docs/available/etd06302004-153939/unrestricted/Models.pdf.

Yoshinaga, A., and Hossain, M. A., 2003: Lysimeter study on sugarcane, Lab. of Water Use \& Hydra. Stru. Engg., Univ. of the Ryukyus, Okinawa, (Un published).

Yamashiro, S., 1990: Studies on some elements concerned with estimation of irrigation for sugarcane. Bull. Univ. of the Ryukyus, Okinawa, Japan, 12;209-219.

Yamashiro, S., Onaga, K., and Yoshinaga, A., 1994; Problems on Agricultural Water Use in Miyako Island, Publication of Sesoko Marine Science Center, Univ. of the Ryukyus, Okinawa Japan, Vol. 12:209-219. 